\title{
鋳型イオン交換体としてのスピネル型マンガン酸化物に よるリチウムイオン取り込み反応の速度論的モデル化
}

\author{
内 保 顕*, 田村 紘基 $^{\circledR *}$, 古市隆三郎*
}

(1995 年 1 月 6 日受付)

(1995 年 3 月 7 日審査終了)

\begin{abstract}
スピネル型マンガン酸化物は, リチウムイオン取り込み反応において，鋳型の作用を示す格子空孔を 持ち，“イオン記憶”イオン交換体として希薄なリチウムイオンの予備濃縮に有望である.この酸化物 を調製し，リチウムイオン取り込み挙動を測定した．空孔へのリチウムイオンの取り込み反応は，酸化 物格子マンガン (IV) イオンによる溶液中の水酸化物イオンの酸化を伴う。反応時間 24 時間までの平 均取り込み速度は, リチウムイオン濃度の増加に対し定常值に漸近するように増加し, 溶液 $\mathrm{pH}$ の増 加に対しては指数関数的に増加する.この反応に対し，（1）格子マンガン (IV)による水酸化物イオン の酸化に伴う格子空孔の励起と，ある割合でのその逆反応，(2) 励起空孔へのリチウムイオンの取り込 み反応の二つの素反応を考えてモデル速度式を導出した。モデルは実測挙動によく適合し，この交換体 の開発や利用に役立つものと期待できる。
\end{abstract}

\section{1 緒 言}

希薄濃度成分の分析においては，定量法の感度向上の ため，あらかじめ目的成分の濃縮を行うことが多い。こ のとき，共存妨害成分から目的成分を選択的に分離でき れば，予備濃縮法として極めて好都合である.この目的 のために, “イオン記憶イオン交換体”1) の開発が試みら れている.これは，鋳型とも呼ばれる，特定イオンのサ イズに適合した空孔を構造中に持つため，あたかもその イオンを記憶しているかのようにふるまうイオン交換体 であり，リチウムイオンに対するスピネル型マンガン酸 化物 $^{2)}$ やカリウムイオンに対する夕ングステン酸化物 ${ }^{3)}$ などが知られている. 又, 最近, 有機イオン交換体で も，表面に鋳型を持つ選択性の高い樹脂を合成する試み がなされている4).

リチウムイオンを対象としたスピネル型マンガン酸化 物は, $\square \mathrm{Mn}_{2} \mathrm{O}_{4}$ ( $\square$ は空孔）の組成を持ち，水溶液中の 希薄なリチウムを分析する際の予備濃縮に応用できるも のと期待できる. 又, 海水に含まれるリチウムの回 収5)6)やリチウム二次電池への応用7) 99) な゙が試みられ ている.

後述のように，このリチウムイオン取り込み反応は,

* 北海道大学工学部機能材料化学講座: 060 北海道札幌 市北区北 13 条西 8 丁目
固液両相で電気的中性を保つために, 酸化物格子マンガ ン (IV) イオンの還元と溶液中の水酸化物イオンの酸化 による酸素発生を伴う ${ }^{10)}$ 。 その速度を追跡し，速度論 的なモデルによって取り込み反応をシミュレートできる ようにすれば，化学分析やイオン分離技術に用いるため の交換体の開発や利用に役立つであろう.

本研究では, スピネル型マンガン酸化物を固相反応法 で調製して, リチウムイオン取り込み挙動を調べ，速度 論的な検討を行った.

$$
2 \text { 実験 }
$$

\section{$2 \cdot 1$ スピネル型マンガン酸化物の調製}

炭酸リチウム（関東化学製，特級）と三二酸化マンガ ン（添川理化学製，99.9\% 以上）を $1: 2$ のモル比で混 合, $850^{\circ} \mathrm{C}$ で 12 時間焼成, 冷却後, 乳鉢で粉砕し再び $850^{\circ} \mathrm{C}$ で焼成するサイクルを 5 回繰り返し，スピネル 型リチウムマンガン酸化物 $\left(\mathrm{LiMn}_{2} \mathrm{O}_{4}\right)$ を調製した. 次に, 得られた粉末約 $30 \mathrm{~g}$ を $1 \mathrm{dm}^{3}$ の $1 \mathrm{~mol} \mathrm{dm}^{-3}$ 硝 酸溶液に浸し, 12 時間かき混ぜたあと, 十分に水洗し てから $70 \sim 80^{\circ} \mathrm{C}$ で乾燥, デシケーター中に保存した.

$2 \cdot 2$ スピネル型マンガン酸化物のキャラクタリゼー ション

調製した酸化物粉末は, 次の方法によりキャラクタラ 


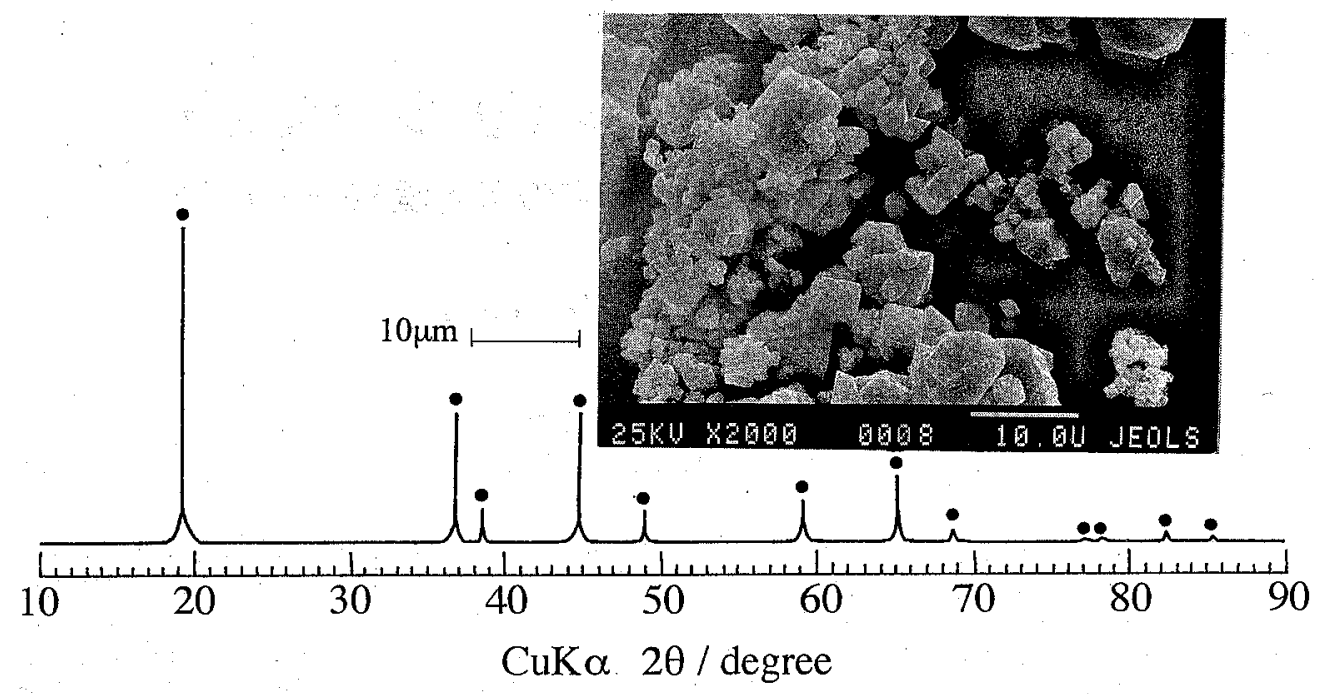

Fig. 1 X-Ray diffraction pattern and scanning electron microscope image of spinel-type manganese oxide

イズした。 (1) XRD (東芝, ME-412G, Gu $\mathrm{K}_{\alpha}$ 線, 回折 ピークにより生成物を同定するとともに内標準として $\mathrm{Si}$ を使用し格子定数を決定). (2) BET 比表面積測定 (Cahn, RG Electrobalance 2050, 重量法による窒素ガ 又吸着量の測定). (3) 原子吸光法に上る組成分析 (日 立, Z-6100, 塩酸ヒドロキシルアンモニウム溶液で試 料粉末を還元溶解し, $\mathrm{Li}^{+}$と $\mathrm{Mn}^{2+}$ の含有量を測定). (4) SEM (JEOL, JSM-35CF，粒子形状とサイズの観 察).

\section{2・3 リチウムイオン取り込み量の測定}

種々の割合の $\mathrm{LiOH}-\mathrm{LiNO}_{3}$ 混合溶液 $\left(\left[\mathrm{Li}^{+}\right]_{\mathrm{T}}\right.$ : $\left.2.34 \times 10^{-3} \sim 2.0 \mathrm{~mol} \mathrm{dm}^{-3}\right) \quad 0.03 \sim 0.22 \mathrm{dm}^{3}$ にスピネル 型マンガン酸化物を $0.25 \sim 0.50 \mathrm{~g}$ 加え, 窒素雾囲気中 $25^{\circ} \mathrm{C}$ でかき混ぜ，1－30 日間反応させた。 $\mathrm{Li}^{+}$取り込 みに伴う $\mathrm{pH}$ の変化を測定するとともに, $\mathrm{Li}^{+}$取り込 み量を次の方法により測定した。 (1) $\mathrm{Li}^{+}$の取り込み反 応は，後述の上うに同一量の $\mathrm{OH}^{-}$の消失を伴うの,で, 滴定あるいは $\mathrm{pH}$ 測定によりアルカリの減少量を求め, 取り込み量とする。(2)溶液中に残存する $\mathrm{Li}^{+}$量を AAS で測定し，添加量との差を取り込み量とする。

\section{3 結果と考察}

\section{$3 \cdot 1$ スピネル型マンガン酸化物の物性}

得られた酸化物は黒色の粉末で, XRD の各回折ピ-
ク (Fig. 1) は，スピネル型マンガン酸化物の文献值 ${ }^{11)}$ (○印）上一致し，格子定数は $8.042 \pm 0.001 \AA$ であっ た. 粉体の BET 比表面積は $15.7 \pm 0.5 \mathrm{~m}^{2} \mathrm{~g}^{-1}$, 各粒子 は立方体であるが，そのサイズにはかなりのばらつきが 見られた（Fig. 1, SEM 写真). 原子吸光法により求め た組成比は, $\mathrm{Li}: \mathrm{Mn}: \mathrm{O}=0.10: 2.04: 4.00$ (酸化物中 の Mn, Li 以外の成分は $\mathrm{O}$ と仮定) であり, この分析 值から予想されるスピネル型マンガン酸化物の組成虹次 のとおりである，すなわち， $\mathrm{Li}^{+}$の抜けた位置が空孔 (口)になっているとす机ば, $\square_{0.90} \mathrm{Li}_{0.10} \mathrm{Mn}$ (III) ${ }_{0.26}$ $\mathrm{Mn}$ (IV) ${ }_{1.78} \mathrm{O}_{4.00}$ ( $\mathrm{Mn} の 87.3 \%$ が四洒) である. 又, 抜けた $\mathrm{Li}^{+}$の位置に $\mathrm{H}^{+}$が置換しているとすれば, $\mathrm{H}_{0.90} \mathrm{Li}_{0.10} \mathrm{Mn}$ (III) ${ }_{1.16} \mathrm{Mn}$ (IV) ${ }_{0.88} \mathrm{O}_{4.00}$ (Mn の $43.1 \%$ が四価）である．この酸化物中のマンガンイオンの酸化 数を酸化還元滴定によって測定したところ（JIS M 8233), 約 $90 \%$ 程度が四価であり, 又, 熱分析の TG-DTA 曲線には脱水ビークが認められなかった。 従 って, 本研究で得たスピネル型マンガン酸化物は, $\square_{0.90} \mathrm{Li}_{0.10} \mathrm{Mn}$ (III) ${ }_{0.26} \mathrm{Mn}$ (IV) ${ }_{1.78} \mathrm{O}_{4.00}$ であると結論し た.ここで, $\mathrm{Li}^{+}$が完全に抜けると, 組成が $\square \mathrm{Mn}$ (IV) ${ }_{2} \mathrm{O}_{4}$ の入- $\mathrm{MnO}_{2}$ になるはずであるが, 本研究で得 られた試料は， $\mathrm{Li}^{+}$が $10 \%$ 残存するとともに Mn(III) イオンの四価への酸化も $90 \%$ 程度にとどまっている. 更に，最大取り込み容量は $5.20 \times 10^{-3} \mathrm{~mol} \mathrm{~g}^{-1}$ であっ たが (Fig. 2)，この值は空孔に $\mathrm{Li}^{+}$が取り込まれて酸 


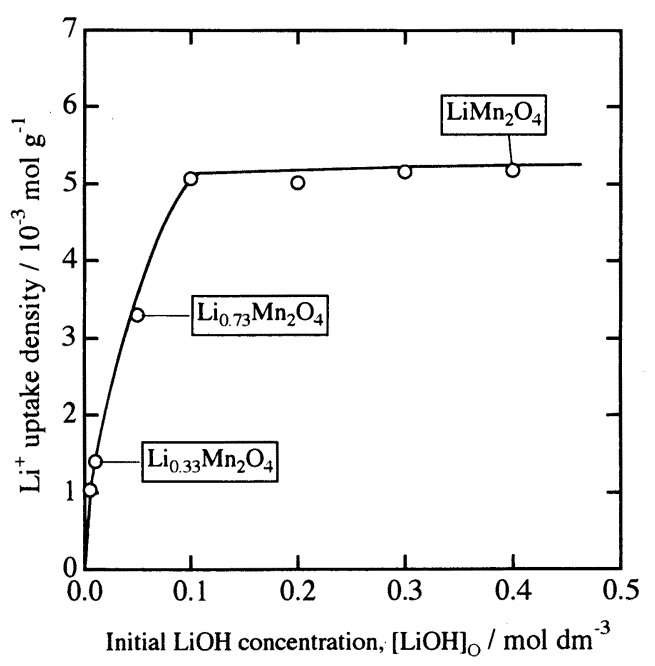

Fig. 2 Lithium ion uptake density as a function of the initial concentration of lithium hydroxide for spinel-type manganese oxide at $8.33 \mathrm{~g} \mathrm{dm}^{-3}$ after 24 $\mathrm{h}$ at $25^{\circ} \mathrm{C}$

化物の組成が $\mathrm{LiMn}_{2} \mathrm{O}_{4}$ になったときに相当し, $\mathrm{Li}^{+}$を 飽和吸着した粉末の溶解分析值 $(2 \cdot 2$, (3) $)$ も $\mathrm{LiMn}_{2} \mathrm{O}_{4}$ の組成に一致した. 又, $\mathrm{Li}^{+}$の取り込みが促進される ように, 試料を $2.0 \mathrm{~mol} \mathrm{dm}{ }^{-3}$ の水酸化リチウム溶液に 10 日間浸したが, $\mathrm{LiMn}_{2} \mathrm{O}_{4}$ の組成以上に $\mathrm{Li}^{+}$を取り 込むことはなかった.

\section{$3 \cdot 2$ イオン取り込み反応の化学量論}

スピネル型マンガン酸化物による $\mathrm{Li}^{+}$の取り込みは 次式に従う ${ }^{10)}$.

$$
\begin{aligned}
& \square \mathrm{Mn}(\mathrm{IV}){ }_{2} \mathrm{O}_{4}+\mathrm{Li}^{+}+\mathrm{OH}^{-} \longrightarrow \\
& \quad \mathrm{LiMn}(\mathrm{IV}) \mathrm{Mn}(\mathrm{III}) \mathrm{O}_{4}+1 / 4 \mathrm{O}_{2}+1 / 2 \mathrm{H}_{2} \mathrm{O}
\end{aligned}
$$

酸化物格子の空孔に $\mathrm{Li}^{+}$を取り込むとき, 格子マンガ ン (IV) が溶液中の $\mathrm{OH}^{-}$を酸化して $\mathrm{Mn}(\mathrm{III}), \mathrm{H}_{2} \mathrm{O}$ 及び $\mathrm{O}_{2}(\mathrm{~g})$ を生じ，固液両相で電気的中性が保たれる. 本研究で調製したスピネル型マンガン酸化物について も，[取り込み $\mathrm{Li}^{+} /$消費 $\mathrm{OH}^{-}$] モル比が 1 であるこ と, 並びに発生気体の助然作用から $\mathrm{O}_{2}$ の生成を確かめ た.

\section{$3 \cdot 3 \mathrm{Li}^{+}$取り込み具の経時変化}

Fig. 3 に, 水酸化リチウム溶液中スピネル型マンガン 酸化物 $1 \mathrm{~g}$ 当たりの $\mathrm{Li}^{+}$取り込み量（取り込み密度）

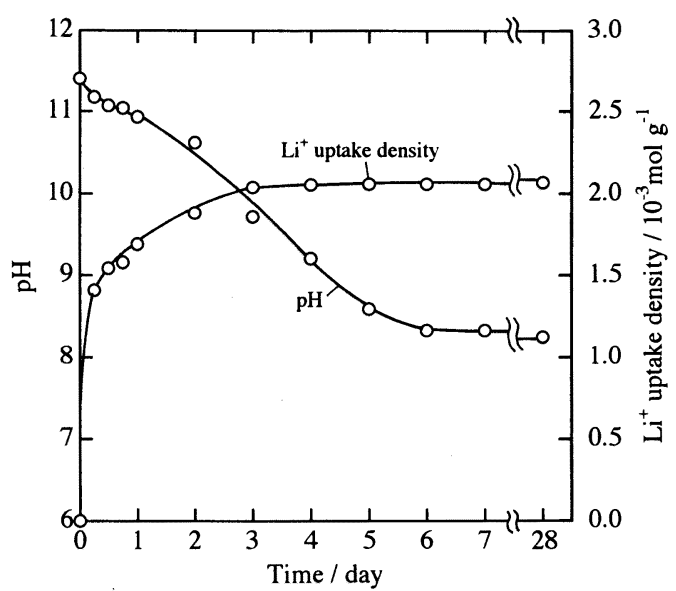

Fig. 3 Time changes in solution $\mathrm{pH}$ and the lithium ion uptake density for a solution containing lithium hydroxide at an initial concentration of $4.55 \times 10^{-3} \mathrm{~mol} \mathrm{dm}^{-3}$ and spinel-type manganese oxide at $2.27 \mathrm{~g} \mathrm{dm}^{-3}$ in nitrogen atmosphere at $25^{\circ} \mathrm{C}$

及び溶液 $\mathrm{pH}$ の時間変化を示す. 時間とともに $\mathrm{Li}^{+}$取 り込み密度が増加し, 溶液 $\mathrm{pH}$ は $\mathrm{Li}^{+}$取り込みに伴う $\mathrm{OH}^{-}$の消費のために低下する. 平衡に達するには, 条 件にもよるが，7〜30日という長時間を必要とした.

\section{$3 \cdot 4 \mathrm{Li}^{+}$取り込み速度と $\mathrm{Li}^{+}$湱度及び $\mathrm{pH}$ との関} 係

種々の濃度と $\mathrm{pH}$ の硝酸リチウム-水酸化リチウム混 合溶液（初期 $\mathrm{pH} 9 \sim 12, \mathrm{Li}^{+}$添加濃度 $10^{-3} \sim 10^{-2}$ $\mathrm{mol} \mathrm{dm}^{-3}$ ) に，スピネル型マンガン酸化物を懸濁して， 24 時間反応後の溶液 $\mathrm{pH}$ と溶液中に残存する $\mathrm{Li}^{+}$の濃 度の関係を Fig. 4 に示した.この結果から，2·3で述 べた方法に従って取り込まれた $\mathrm{Li}^{+}$量を求め, $\mathrm{Li}^{+}$取 り込み密度 $\left(\mathrm{mol} \mathrm{g}^{-1}\right)$ を計算し, 残存 $\mathrm{Li}^{+}$濃度に対し てプロットした (Fig. 5, 左縦軸)。この取り込み密度 を反応時間 (24 時間) で割れば, 反応時間 1 日の平均 取り込み速度 $V\left(\mathrm{~mol} \mathrm{~g}^{-1} \mathrm{day}^{-1}\right)$ の值が得られる (Fig. 5, 右縦軸). $V$ の值は $\mathrm{Li}^{+}$濃度の上昇とともに増 加するが，曲線は上に凸で頭打ち傾向を示す．しかし， 取り込み密度は全取り込み容量 $\left(5.20 \times 10^{-3} \mathrm{~mol} \mathrm{~g}^{-1}\right)$ に比べて十分に小さい（最大で約 20\%）ので，頭打ち になるのは取り込み量が飽和に近づくことによるもので はないと考えられる.

次に, Fig. 5 の結果から同一 $\mathrm{Li}^{+}$濃度で取り込み速 


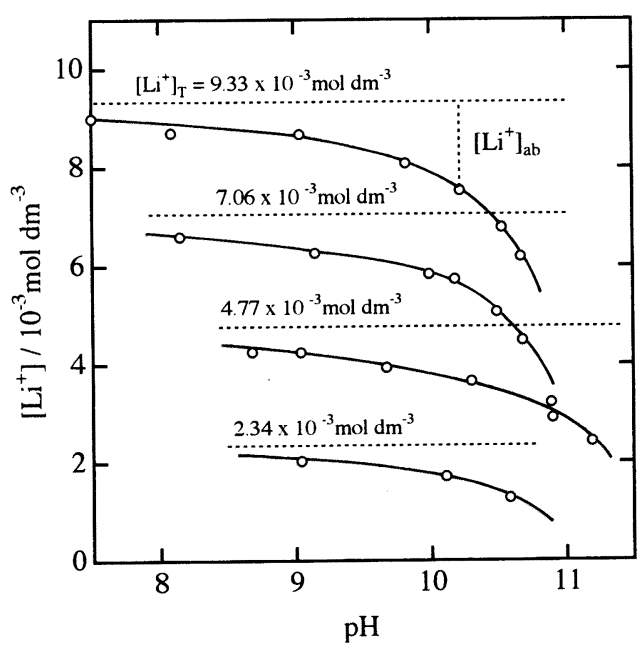

Fig. 4 Change in lithium ion concentration as a function of $\mathrm{pH}$ for $\mathrm{LiOH} / \mathrm{LiNO}_{3}$ solutions (with different ratios and different total lithium concentrations) containing spinel-type manganese oxide at $2.27 \mathrm{~g} \mathrm{dm}^{-3}$ in nitrogen atmosphere after $24 \mathrm{~h}$ at $25^{\circ} \mathrm{C}$

$\left[\mathrm{Li}^{+}\right]_{\mathrm{T}}$ : total lithium ion concentration; $\left[\mathrm{Li}^{+}\right]_{\mathrm{ab}}$ : absorbed lithium ion concentration

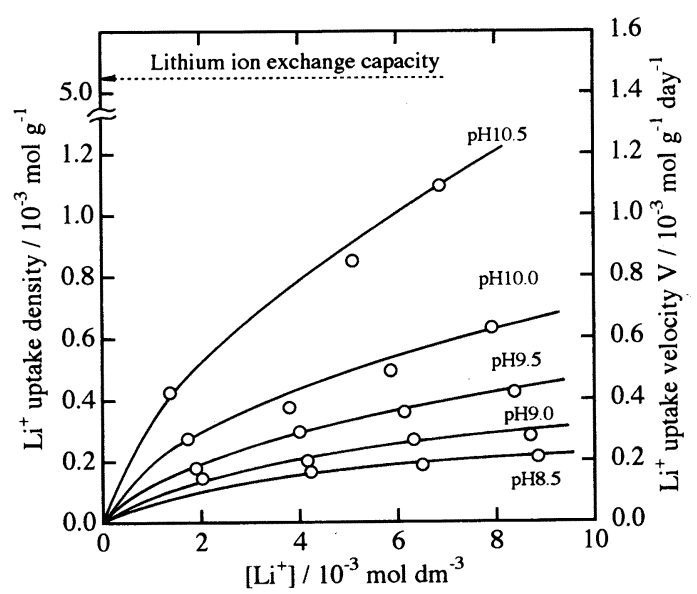

Fig. 5 Lithium ion uptake density or velocity $V$ as a function of lithium ion concentration at different $\mathrm{pH}$ for spinel-type manganese oxide in nitrogen atmosphere after $24 \mathrm{~h}$ at $25^{\circ} \mathrm{C}$

度 $V$ (取り込み密度) を読みとり, 溶液 $\mathrm{pH}$ に対してプ ロットした (Fig. 6). $\mathrm{Li}^{+}$取り込み速度 $V$ は, $\mathrm{pH} の$ 上昇とともに下に凸の曲線となって指数関数的に増加し

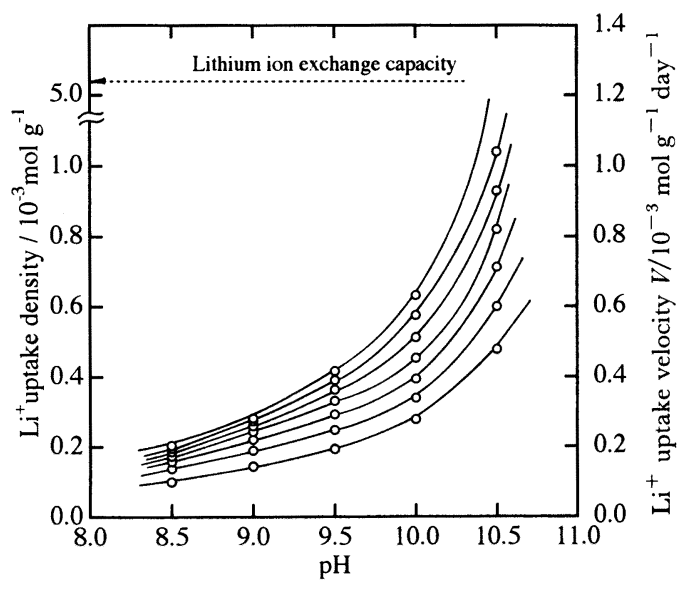

Fig. 6 Lithium ion uptake density or velocity $V$ as a function of $\mathrm{pH}$ with lithium ion concentrations of 2, 3, 4, 5, 6, 7, $8 \times 10^{-3} \mathrm{~mol} \mathrm{dm}^{-3}$ (from bottom to top) for spinel manganese oxide in nitrogen atmosphere after $24 \mathrm{~h}$ at $25^{\circ} \mathrm{C}$

Solid phase Liquid phase

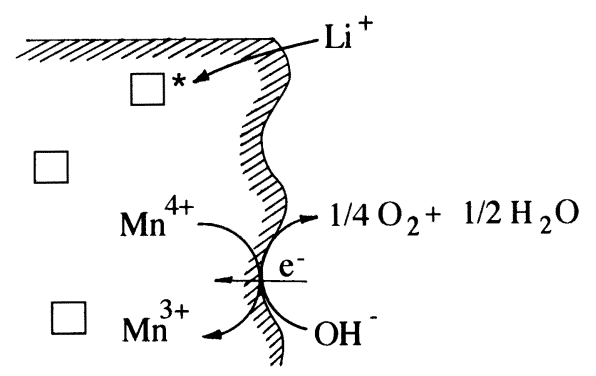

Fig. 7 Mechanism of lithium ion uptake reaction on spinel-type manganese oxide

ている.

\section{$3 \cdot 5 \mathrm{Li}^{+}$取り込み反応の速度論的モデル}

取り込み反応の化学量論式 (1)に基づき, この反応を (a) 格子 $\mathrm{Mn}(\mathrm{IV})$ による溶液中の $\mathrm{OH}^{-}$の酸化と格子 空孔の励起, (b) 励起空孔への $\mathrm{Li}^{+}$の侵入の二つの逐次 反応に分けた (Fig. 7). $\mathrm{Li}^{+}$取り込み反応の総括反応 速度は, 以下に示すように, 反応 $(\mathrm{a})$, （b）の速度によ って決定されるものと仮定する. 


$$
\begin{aligned}
& \text { (a) } \equiv \mathrm{Mn}(\mathrm{IV})+\mathrm{OH}^{-}+\square \\
& \stackrel{k_{1}}{\overrightarrow{k_{-1}}} \equiv \mathrm{Mn}(\mathrm{III})+\square^{*}+1 / 4 \mathrm{O}_{2}+1 / 2 \mathrm{H}_{2} \mathrm{O}(2) \\
& \text { (b) } \square^{*}+\mathrm{Li}^{+} \stackrel{k_{2}}{\longrightarrow} \equiv \mathrm{Li}(\mathrm{I})
\end{aligned}
$$

ここで, 酸化物格子マンガン (IV) イオン $(\equiv \mathrm{Mn}(\mathrm{IV}))$ は, 溶液中の水酸化物イオンを酸化して $\equiv \mathrm{Mn}(\mathrm{III})$ に なり，このとき空孔が励起されるものと考える. 励起空 孔 $\left(\square^{*}\right)$ が, 溶液から $\mathrm{Li}^{+}$を取り込み, 格子 $\mathrm{Li}(\mathrm{I})$ イオンサイト（三Li(I)）が生成すると反応が完結する.

反応 (a)では, ある割合で逆反応が起こり, 反応 (b) では正方向の反応のみが起こるとし, 式 ( 2 ), (3) 中の, $k_{1}, k_{-1}, k_{2}$ は各素反応の速度定数である.ここ で, 励起空孔 1 個の生成は固相で +1 の電荷の消失, 液相で -1 の電荷の消失を伴い, 固液両相でそれぞれ 電荷の不均衡が起きる. 従って, 励起空孔は不安定な反 応中間体であり, 生成すると同時に反応 (a) の逆反応 及び反応 (b) によって消失し, その密度 $\left[\square^{*}\right]$ は微少 な定常值を取るものと考えられる. $\mathrm{Li}^{+}$イオン取り込 みは遅い反応で 24 時間後でも多量の原料成分が残存す るので, 励起空孔密度は反応成分の密度に比して無視で き, 定常状態近似が適用できるものとすれば,

$$
\begin{aligned}
\frac{\mathrm{d}\left[\square^{*}\right]}{\mathrm{d} t}= & k_{1}[\equiv \mathrm{Mn}(\mathrm{IV})]\left[\mathrm{OH}^{-}\right][\square] \\
& -k_{-1}[\equiv \mathrm{Mn}(\mathrm{III})]\left[\square^{*}\right]{P \mathrm{o}_{2}}^{0.25} \\
& -k_{2}\left[\square^{*}\right]\left[\mathrm{Li}^{+}\right]=0
\end{aligned}
$$

ここで，［］は固体成分については固体中の密度 $(\mathrm{mol}$ $\left.\mathrm{g}^{-1}\right)$, 溶液成分については濃度 $\left(\mathrm{mol} \mathrm{dm}^{-3}\right)$ を表す. 式 (4) より, 励起空孔の定常密度は次式となる.

$$
\left[\square^{*}\right]=\frac{k_{1}[\equiv \mathrm{Mn}(\mathrm{IV})]\left[\mathrm{OH}^{-}\right][\square]}{k_{-1}[\equiv \mathrm{Mn}(\mathrm{III})] P_{\mathrm{O}_{2}}{ }^{0.25}+k_{2}\left[\mathrm{Li}^{+}\right]}
$$

これを用いると, $\mathrm{Li}^{+}$の取り込み速度は次式で表され る.

$$
\begin{aligned}
V & =k_{2}\left[\square^{*}\right]\left[\mathrm{Li}^{+}\right] \\
& =\frac{k_{1} k_{2}[\equiv \mathrm{Mn}(\mathrm{IV})]\left[\mathrm{Li}^{+}\right]\left[\mathrm{OH}^{-}\right][\square]}{k_{-1}[\equiv \mathrm{Mn}(\mathrm{III})] \mathrm{Po}_{2}{ }^{0.25}+k_{2}\left[\mathrm{Li}^{+}\right]}
\end{aligned}
$$

ここで, 反応開始時の各格子サイトの密度を酸化物の組 成式から求めると, $[\equiv \mathrm{Mn}(\mathrm{IV})]=1.01 \times 10^{-2} \mathrm{~mol} \mathrm{~g}^{-1}$, $[\square]=5.09 \times 10^{-3} \mathrm{~mol} \mathrm{~g}^{-1}$ であるが, 本実験の条件では $\mathrm{Li}^{+}$取り込み密度は最大でも $1.1 \times 10^{-3} \mathrm{~mol} \mathrm{~g}^{-1}$ 程度な ので,これらの密度値は実験を通してほぼ一定とみなせ
る. 又, $\equiv \mathrm{Mn}(\mathrm{III})$ は反応生成物であるが, 試料酸化 物は初めからこれを $[\equiv \mathrm{Mn}(\mathrm{III})]=1.47 \times 10^{-3} \mathrm{~mol} \mathrm{~g}^{-1}$ の密度で含んでいる. 従って, $\mathrm{Li}^{+}$取り込み量の少な い条件では, この項も一定と見なせる. 又, $\mathrm{Po}_{2}{ }^{0.25}$ は, 窒素吹き込み条件下で, 微少な一定值に保たれているも のと考えられる.

いま, $\mathrm{pH}$ すなわち $\left[\mathrm{OH}^{-}\right]$が一定のとき, $k_{\mathrm{a}}=k_{1} k_{2}$ $[\equiv \mathrm{Mn}(\mathrm{IV})]\left[\mathrm{OH}^{-}\right][\square], k_{\mathrm{b}}=k_{-1}[\equiv \mathrm{Mn}(\mathrm{III})] P_{\mathrm{O}_{2}}{ }^{0.25}$ とおくと, 式 $(6)$ は

$$
V=k_{\mathrm{a}}\left[\mathrm{Li}^{+}\right] /\left(k_{\mathrm{b}}+k_{2}\left[\mathrm{Li}^{+}\right]\right)
$$

となる. 式 (7)において, $\left[\mathrm{Li}^{+}\right]$濃度の増加により $k_{\mathrm{b}} \ll k_{2}\left[\mathrm{Li}^{+}\right]$になれば, $V$ は一定值 $\left(k_{\mathrm{a}} / k_{2}\right)$ に近づく. $k_{\mathrm{a}} / k_{2}$ 值は, $k_{\mathrm{a}}$ が $\left[\mathrm{OH}^{-}\right]$を含むので $\mathrm{pH}$ が高いほど大 きい.このように式 ( 7 ) は, Fig. 5 の実測の $V$ の頭打 ち挙動を説明できるが，このモデル速度式と実測值の一 致を次のように検討した. 式 ( 7 )の両辺の逆数を取る 之, 次式が得られる.

$$
V^{-1}=\left(k_{\mathrm{b}} / k_{\mathrm{a}}\right)\left[\mathrm{Li}^{+}\right]^{-1}+k_{2} / k_{\mathrm{a}}
$$

Fig. 5 に示した值から $V^{-1}$ と $\left[\mathrm{Li}^{+}\right]^{-1}$ の関係をプロッ

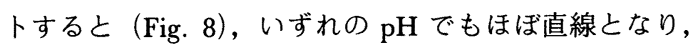
切片が $k_{2} / k_{\mathrm{a}}$, 傾きが $k_{\mathrm{b}} / k_{\mathrm{a}}$ の直線関係式 ( 8 ) が成立し, モデル速度式 ( 7 ) は妥当である.

次に, $\left[\mathrm{Li}^{+}\right]$が一定のとき, $k_{\mathrm{a}}{ }^{\prime}=k_{1} k_{2}[\equiv \mathrm{Mn}(\mathrm{IV})]$ $\left[\mathrm{Li}^{+}\right][\square], k_{\mathrm{b}}{ }^{\prime}=k_{-1}[\equiv \mathrm{Mn}(\mathrm{III})] \mathrm{Po}_{2}{ }^{0.25}+k_{2}\left[\mathrm{~L}^{+}\right]$とお くと, 式(6)は次式となる.

$$
V=k_{\mathrm{a}}{ }^{\prime}\left[\mathrm{OH}^{-}\right] / k_{\mathrm{b}}{ }^{\prime}=\left(k_{\mathrm{a}}, K_{\mathrm{w}} 10^{\mathrm{pH}}\right) / k_{\mathrm{b}}{ }^{\prime}
$$

$k_{\mathrm{a}}, k_{\mathrm{b}}$ と同様, $k_{\mathrm{a}}{ }^{\prime}, k_{\mathrm{b}}{ }^{\prime}$ は定数とみなせるので， $V$ は $\left[\mathrm{OH}^{-}\right]$に比例し, $\mathrm{pH}$ に対して指数関数的に増大する. このモデル速度式と実測値の一致を次のように検討し た. 式 ( 9 )の両辺の対数を取ると, 式(10)が得られる.

$$
\log V=\log \left(k_{\mathrm{a}} K_{\mathrm{w}} / k_{\mathrm{b}}{ }^{\prime}\right)+\mathrm{pH}
$$

Fig. 6 に示した結果から $\log V$ と $\mathrm{pH}$ の関係をプロット すると (Fig. 9), $\log V$ はいずれの $\left[\mathrm{Li}^{+}\right]$でも $\mathrm{pH}$ と ともに増加し, $V$ の $\mathrm{pH}$ に対する指数関数的増加挙動が 説明できる.しかし，直線の傾きは約 0.65 であり，モ デル式(10)が示す傾き1には一致していない。このこ とは, 式 (10)中の $k_{\mathrm{a}}{ }^{\prime} / k_{\mathrm{b}}{ }^{\prime}$ の項が, 水素イオン濃度の関 数であることを示唆している. $k_{\mathrm{a}}{ }^{\prime} / k_{\mathrm{b}}{ }^{\prime}$ 項に含まれる各速 度定数のう $5, k_{1}$ は次のように水素イオン濃度の関数 となり得る。まず， $k_{1}$ が関係する式 ( 2 )の正反応は, 次のように酸化物への $\mathrm{OH}^{-}$イオンの吸着の前置平衡 


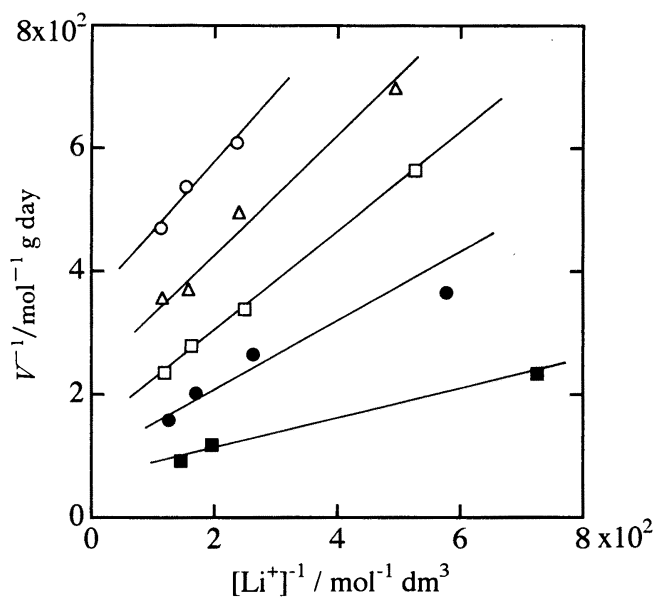

Fig. 8 Relationships between $1 / V$ and $1 /\left[\mathrm{Li}^{+}\right]$for different $\mathrm{pH}$

$\mathrm{pH}: 8.5(\bigcirc), 9.0(\triangle), 9.5(\square), 10.0(\bigcirc), 10.5(\square)$

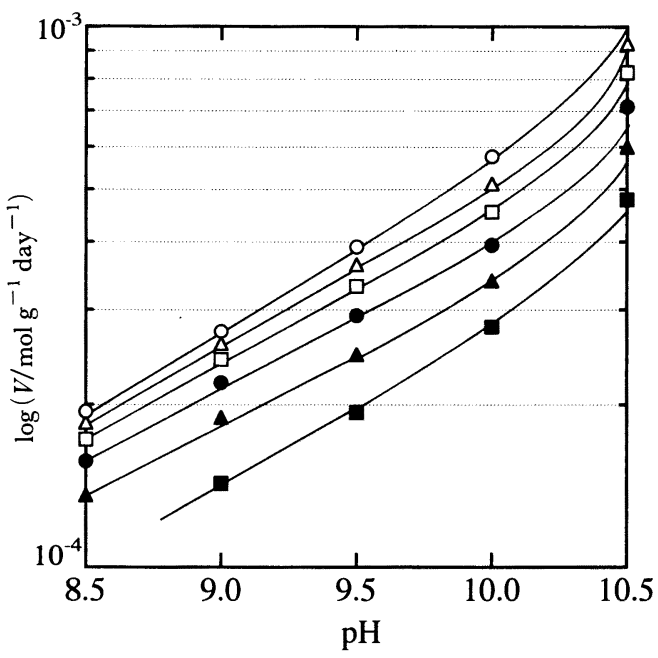

Fig. 9 Relationships between $\log V$ and $\mathrm{pH}$ for different lithium ion concentrations

$\left[\mathrm{Li}^{+}\right] / 10^{-3} \mathrm{~mol} \mathrm{dm}{ }^{-3}: 7(\bigcirc), 6(\triangle), 5(\square), 4(\bigcirc)$, $3(\mathbf{\Delta}), 2(\mathbf{\square})$

(11) と吸着 $\mathrm{OH}^{-}$イオン, $\mathrm{OH}^{-}{ }_{\mathrm{ad}}$ の酸化反応 (12)に分 けることができる.

$$
\begin{aligned}
& \mathrm{OH}^{-} \rightleftarrows \mathrm{OH}^{-}{ }_{\text {ad }} \\
& \equiv \mathrm{Mn}(\mathrm{IV})+\mathrm{OH}^{-}{ }_{\text {ad }} \longrightarrow \\
& \quad \equiv \mathrm{Mn}(\mathrm{III})+1 / 4 \mathrm{O}_{2}+1 / 2 \mathrm{H}_{2} \mathrm{O}
\end{aligned}
$$

金属酸化物は, 一般に水溶液中で固液界面電位差 $\psi$ を 示し, $\mathrm{OH}^{-}$の吸着はその影響を受け, 吸着反応(11)の 平衡定数 $K^{\mathrm{o}}$ は次のように表せる ${ }^{12)}$.

$$
K^{\circ}=\frac{\left[\mathrm{OH}^{-}{ }_{\text {ad }}\right]}{\left[\mathrm{OH}^{-}\right]} \exp (-F \psi / R T)
$$

ここで, $F$ はファラデー定数, $R$ は気体定数, $T$ は絶対 温度である. 次に, 反応 $(12)$ の速度定数を $k_{1}{ }^{\prime}$ とすれ ば, 反応 $(2)$ の速度定数 $k_{1}$ は次式となる.

$$
k_{1}=k_{1}{ }^{\prime} K^{\circ} \exp (F \psi / R T)
$$

これを式(10)に代入すれば次式が得られる.

$$
\log V=\log \left(k_{\mathrm{a}}{ }^{\prime \prime} K_{\mathrm{w}} / k_{\mathrm{b}}{ }^{\prime}\right)+F \psi \log \mathrm{e} / R T+\mathrm{pH}
$$

ここで, $k_{\mathrm{a}}{ }^{\prime \prime}=k_{1}{ }^{\prime} K^{\mathrm{o}} k_{2}[\equiv \mathrm{Mn}(\mathrm{IV})]\left[\mathrm{Li}^{+}\right][\square]$ である. 一般の二酸化マンガンの電荷は $\mathrm{pH}$ 4 5 以上で負で, その絶対値は $\mathrm{pH}$ と共に増加する ${ }^{13) 14)}$. 本研究のスピ ネル型マンガン酸化物が同様の荷電挙動を示すとすれ ば，式(15)右辺第 2 項の $\phi$ は負でその絶対值が $\mathrm{pH}$ と 共に増加することになり, $\log V$ vs. $\mathrm{pH}$ プロットの傾き が 1 より小となることが説明できる.

スピネル型マンガン酸化物によるリチウムイオン取り 込み反応の進行とともに, $\mathrm{Mn}(\mathrm{IV})$ は $\mathrm{Mn}(\mathrm{III})$ へ還元 され, 空孔密度は減少していくが, このとき反応が酸化 物相全体で均一に進行するか，あるいは局所的に（例え ば表面で）進行するかという疑問が生ずる．小沢 ${ }^{15)} に$ よれば，電池材料の $\mathrm{MnO}_{2}$ の放電において，酸化物中 の $\mathrm{Mn}(\mathrm{IV}) / \mathrm{Mn}(\mathrm{III})$ 比は, 酸化物相全体にわたって常 に均一に変化し，その電位は均一水溶液系のように Nernst の式で表示できるという。これは放電により酸 化物中に取り込まれた電子と電気的中性を保つために溶 液相から侵入した $\mathrm{H}^{+}$が，共に自由に酸化物中を移動 できるためと考えられている．スピネル型マンガン酸化 物中でも同様に電子の移動は速く，サイズの小さい $\mathrm{Li}^{+}$の自由度は大きいので'6), $\mathrm{Mn}(\mathrm{IV}) / \mathrm{Mn}(\mathrm{III})$ 比及 び空孔密度は酸化物全体にわたって均一に変化していく ものと推定される。

以上，スピネル型マンガン酸化物によるリチウムイオ ン取り込み反応に対し，空孔の励起反応と励起空孔への $\mathrm{Li}^{+}$取り込み反応を考えてモデル速度式を導出し，反 応時間 24 時間までの $\mathrm{Li}^{+}$の平均取り込み速度 $V$ と $\mathrm{Li}^{+}$濃度及び $\mathrm{pH}$ との関係を説明した.

本研究の一部は, 文部省科学研究費補助金 (課題番号 05680438）によった。 又, 本研究に際し XRD, SEM 装置 を, 北海道大学工学部機能材料化学講座の小平紘平, 稲垣 道夫両教授から借用した。付記して謝意を表する. 


\section{文献}

1）妹尾 学, 阿部光雄, 鈴木 喬: “イオン交換”, p. 249 (1991), (講談社).

2) J. C. Hunter: J. Solid State Chem., 39, 142 (1981).

3）鈴木 喬, 三宅通博, 吉川工ミ, 吉田敏行: 日本海 水学会誌, 44, 185 (1990).

4) K. Tsukagoshi, K. Y. Yu, M. Maeda, T. Takagi: Bull. Chem. Soc. Jpn., 66, 114 (1993).

5) K. Ooi, Y. Miyai, S. Katoh: Sep. Sci. Technol., 22, 1779 (1987).

6) K. Ooi, Y. Miyai, S. Katoh: Sep. Sci. Technol., 23, 179 (1988).

7) M. M. Thackeray, A de Kock, M. H. Rossouw, D. Liles, R. Bittihn, D. Hoge: J. Electrochem. Soc., 139, 363 (1992).

8) D. Guyomard, J. M. Tarascon: J. Electrochem. Soc., 139, 937 (1992).

Modeling of the kinetics of lithium ion incorporation into a spinel type manganese oxide, a template ion exchanger. Akira Uchibo, Hiroki TAMURA and Ryusaburo Furuichi (Research Group of Materials Chemistry, Faculty of Engineering, Hokkaido University, Kita-13, Nishi-8, Kita-ku, Sapporo-shi, Hokkaido 060)

A "lithium ion memory" template ion exchanger, a spinel type manganese oxide ( $\left.\mathrm{Mn}_{2} \mathrm{O}_{4}\right)$ with vacancies $(\square)$, has shown promise for preliminary concentration of trace lithium ions in natural environments. This oxide was prepared by topotactic extraction of lithium with nitric acid from a spinel type $\mathrm{LiMn}_{2} \mathrm{O}_{4}$, which was obtained by a solidphase reaction between $\mathrm{Li}_{2} \mathrm{CO}_{3}$ and $\mathrm{Mn}_{2} \mathrm{O}_{3}$ at $850^{\circ} \mathrm{C}$. The formed spinel type manganese oxide was characterized by XRD, SEM, AAS, and BET surface area measurements. The amount of lithium ions incorporated into the oxide was measured by AAS of lithium ions in solution and by an analysis of hydroxide ions in solution with $\mathrm{pH}$ measurements or titration according to the stoichiometry shown below. The lithium ion uptake reaction was maintained for more than one month, and the stoichiometry was confirmed as, $\square \mathrm{Mn}(\mathrm{IV})_{2} \mathrm{O}_{4}+\mathrm{Li}^{+}+\mathrm{OH}^{-} \longrightarrow \mathrm{LiMn}(\mathrm{III}) \mathrm{Mn}(\mathrm{IV}) \mathrm{O}_{4}+1 / 4 \mathrm{O}_{2}+1 / 2 \mathrm{H}_{2} \mathrm{O}$. The average velocity of $\mathrm{Li}^{+}$incorporation for 1 day, $V$, increases with the lithium ion concentration tending towards limiting values, while it increases exponentially with $\mathrm{pH}$.

The following kinetic model was proposed: (1) $\equiv \mathrm{Mn}(\mathrm{IV})+\mathrm{OH}^{-}+\square \underset{k_{2}}{\stackrel{k_{1}}{\rightleftarrows}}$ $\equiv \mathrm{Mn}(\mathrm{III})+\square^{*}+1 / 4 \mathrm{O}_{2}+1 / 2 \mathrm{H}_{2} \mathrm{O}$, and (2) $\square^{*}+\mathrm{Li}^{+} \stackrel{k_{2}}{\longrightarrow} \equiv \mathrm{Li}(\mathrm{I})$, where $k_{1}, k_{-1}$, and $k_{2}$ are the rate constants of respective elementary reactions. This assumes that the oxidation of a hydroxide ion by the lattice $\mathrm{Mn}(\mathrm{IV})$ ion excites a vacancy with a slight backward reaction and that the excited vacancy takes up a lithium ion. The rate equation for $V$ obtained by applying the steady state approximation to the excited vacancy explained the observed results well.

(Received January 6, 1995)

(Accepted March 7, 1995)

\section{Keyword phrases}

spinel type manganese oxide; lithium ion; ion-memory template exchanger; lattice vacancy; kinetic modeling. 